\title{
An Updated Diversity Pattern of Chalcididae (Hymenoptera: Chalcidoidea) between Disturbed and Undisturbed Forest of Meghalaya with Some New Records
}

\section{Bankerdonbor Kharbisnop*, Sudhanya Ray Hajong \\ Department of Zoology, North Eastern Hill University, Mawlai Umshing Mawkynroh, Shillong 793022, Meghalaya, India \\ Study Area: Mawsynram, Uppershillong and Nongpoh, Meghalaya, India \\ Coordinates: $25^{\circ} 17^{\prime} 55^{\prime \prime} \mathrm{N}$; $91^{\circ} 34^{\prime} 56^{\prime \prime} \mathrm{E}$; - $25^{\circ} 33^{\prime} 47^{\prime \prime}$ $\mathrm{N} ; 91^{\circ} 50^{\prime} 81^{\prime \prime E}$; \& $25^{\circ} 54^{\prime} 8^{\prime \prime} \mathrm{N} ; 91^{\circ} 52^{\prime} 37^{\prime \prime} \mathrm{E}$}

Key words: Northeast India, New faunal records, Forest types

\section{Introduction:}

The members of Chalcididae are primary endoparasitoids of insects belonging to the order Lepidoptera, Diptera, Hymenoptera, Coleoptera and Neuroptera respectively (Iqbal \& Inayatullah, 2015). About 1530 species under 90 genera were globally distributed and 645 species of chalcids was recorded from India (Noyes, 2015; www.nhm.ac.uk/ chalcidoids). Brachymeria (Westwood) belongs to Brachymeriini under subfamily Chalcidinae and is highly diversified with 350 described species worldwide (Delvare, 2017). The genus Brachymeria (Westwood) is highly speciose among the members of Chalcididae and also has a wider host range, attacking various insect orders like Orthoptera, pupae of most Lepidoptera, Diptera and Coleoptera and rarely as hyperparasitoids of Hymenoptera (Bouèek, 1952; Joseph et al., 1973). 76 species of Brachymeria (Westwood) were recorded from India and 22 species were documented among 8 Northeastern states of India (Noyes, 2019; www.nhm.ac.uk/chalcidoids). Antrocephalus Kirby, Hockeria Walker, Kriechbaumerella Dalla Torre and Haltichella Spinola belong to Halchillinae under Haltichella genus group which includes the genera Euchalcis, Haltichella, Hockeria, Kriechbaumerella and Oxycoryphe. Antrocephalus contributes a valid of 126 described species parasitized the host belonging to the families Tortricidae, Oecophoridae, Pyralidae and Crambidae under Lepidoptera. Some species use as parasitoids of phyllophagous moths and bruchid beetles.

\section{Abstract}

A survey on Chalcidoidea in Meghalaya was conducted. One genus Kriechbaumerella was recorded for the first time in the Mawsynram, Uppershillong and Nongpoh, Meghalaya for Meghalaya. Ten species (Brachymeria aurea, Brachymeria coxadentata, Antrocephalus carnifrons, Antrocephalus subelongatus, Antrocephalus mitys, Antrocephalus validicornis, Hockeria bengalorica, Hockeria bifaciata, Kriechbaumerella destructor and Haltichella sp.) were a new distributional records for the Northeastern region including the state of Meghalaya. The genera collected from the undisturbed and disturbed forest from three different selected sites under East Khasi Hills and Ribhoi Districts were analysed.

Haltichella Spinola recorded 36 species globally and are parasitoids to the families of Lepidoptera (Bucculatricidae; Gelechiidae; Momphidae; Notodontidae; Oecophoridae; Pyralidae; Tortricidae) and Hymenoptera (Braconidae; Ichneumonidae) (Noyes, 2011; www.nhm.ac.uk/ entomology/chalcidoids/index.html). The genus Hockeria Walker was recorded a total of 106 described species globally. They are the parasitoids on pupae of various families belonging to Lepidoptera, Strepsiptera (Boucek, 1988) Neuroptera and Hymenoptera (Diprionidae) (Boucek and Delvare, 1992). Kriechbaumerella includes 25 valid species worldwide and the known hosts belong to families Limacodidae, Lasiocampidae and Saturniidae mostly large moths (Delvare, 2017). India recorded 21 described species of Antrocephalus, 7 species in Haltichella, Hockeria with 24 described species and 11 species for Kreichbaumerella. From the North-Eastern region of India, 5 described species of Antrocephalus were reported, Hockeria and Kriechbaumerella listed 2 described species each and Haltichella with a single undescribed species (Sheela et al., 2003; Noyes, 2019). The Chalcids fauna in Meghalaya is very low. 8 described species of Brachymeria were recorded so far. Brachymeria shillongensis was the first Brachymeria species documented in the state (Narendran, 1986). Thakur (1990) recorded Brachymeria lasus. Twenty years later another species Brachymeria jambolana was reported from Meghalaya (Gupta, 2010). Gowriprakash (2019) in her thesis reports 7 species under Brachymeria. There has no 
record so far for the genus Kreichbaumerella from Meghalaya. This paper highlights a new distributional record of a single genus and ten species from Meghalaya. Data were analysed based on the specimens collected from undisturbed and disturbed forests of three selected study sites with a comparison of both the forest types.

\section{Methodology:}

Sampling was conducted for a period of two years (February 2017 to March 2019). Three study sites viz., Mawsynram, Upper Shillong and Nongpoh were selected for the sample collection. The selected area shows the different ranges of temperatures with different vegetation types. Mawsynram located at $25^{\circ} 17^{\prime} 55^{\prime \prime} \mathrm{N}$ and $91^{\circ} 34^{\prime} 56^{\prime \prime} \mathrm{E}$ with an altitude of about 1,532 metres in East Khasi Hills District, holds a record for receiving the most rainfall in the world. The forest in this study site is temperate type. Upper-Shillong with a Latitude $25^{\circ} 33^{\prime} 47^{\prime \prime} \mathrm{N}$ and Longitude $91^{\circ} 50^{\prime} 81^{\prime \prime} \mathrm{E}$ and an elevation of $1652 \mathrm{~m}$ above sea level are a Subtropical and broadleaf forest with Pinus kesiya as the dominant tree species. Nongpoh with latitude $25^{\circ} 54^{\prime} 8$ " $\mathrm{N}$ and longitude $91^{\circ} 52^{\prime} 37^{\prime \prime}$ E and an elevation of 508 metres above mean sea level is mostly covered by dense forests of tropical and deciduous types. The area is the hot and humid border to the neighbouring state of Assam. The method of collection was followed by Noyes (1982). Yellow Pan Trap and sweep net were used during the survey. For YPT, a soap solution and a pinch of salt were added displayed in study sites for 22 to 24 hours. A distance of 5 meters in vegetative areas was selected for sweeping. The samples were then brought to the laboratory, separated into different families, genera and species and kept in a refrigerator. The samples were then identified using available literature by Mani (1989), Narendran et al. (2016) and Delvare (2017). All specimens were deposited in the Entomology Laboratory, Department of Zoology, North-Eastern Hill University. Abbreviations were used for $\mathrm{UD}=$ Undisturbed, $\mathrm{D}=$ Disturbed, YPT=Yellow Pan Trap, SN=Sweep Net.

\section{Ourobservations:}

During our survey on Chalcidoidea of Meghalaya in the year, 2017 to 2019 very few samples on the Chalcididae family were collected. From our experiment, we found out that more members of Chalcididae were collected from the undisturbed forest as compared to disturbed forest. A total of 122 samples were collected from three different collecting sites. 63 samples in 2017-18 and 59 samples in 2018-19 were collected from undisturbed and disturbed forests of the selected study site. Five genera (Table: 1 ) were found to be the most dominant in the state. Antrocephalus with a record of four species A.subelongatus Kohl (Plate-1a), A.mitys Walker (Plate-1b), A.carnifrons Cameron (Plate-1c), A.validicornis Holmgren (Plate-1d), Brachymeria were represented by B.minuta Linnaeus (Plate-1e), B.jambolana Gahan (Plate-1f), B.euploeae Westwood (Plate-1g), B.aurea Girault (Plate-1h), B.coxodentata Joseph et al. (Plate-1i), Kriechbaumerella by a described species of K.dustructor Waterston (Plate-1j), Hockeria by H.bengalorica
Narendran (Plate-1k), H.bifaciata Walker (Plate-1l) and unidentified species of Haltichella (Plate-1m). Ten species Antrocephalus carnifrons Cameron, A.mitys Walker, A.subelongatus Kohl, A.validicornis Holmgren, Brachymeria aurea Girault, B.coxodentata Joseph et al., H.bengalorica Narendran, H.bifaciata Walker, Kriechbaumerella dustructor Waterston and an undescribed species of the genus Haltichella Spinola were reported for the first time in Northeast India and in Meghalaya.

Analysis of the distribution of chalcids was done for the genus only. On analysing the data from the undisturbed and disturbed forest, in February 2017- January 2018 a total of 49 and 14 individuals from undisturbed and disturbed were collected respectively. Out of these Antrocephalus were recorded $12(\mathrm{UD}=10, \mathrm{D}=2)$, Brachymeria with a total of $26(\mathrm{UD}=18, \mathrm{D}=8)$ individuals, Hockeria with $17(\mathrm{UD}=13$, $\mathrm{D}=4$ ), Haltichella recorded 7 individuals and a single individual of Kriechbaumerella both were collected from the undisturbed forest. In February 2018- January 2019, a total of 53 individuals were collected from undisturbed and 6 from disturbed forests respectively. From these collections, Antrocephalus was recorded 7 (all collected from the undisturbed forest), Brachymeria with a total of 15 (specimens collected from the undisturbed forest only) individuals, Hockeria with $23(\mathrm{UD}=17, \mathrm{D}=6)$ individuals, Haltichella with 14 individuals collected from undisturbed areas and with no collection of Kriechbaumerella. The specimens were also analysed based on the type of method involved in the collection (Table-2), though two methods

Table-1: Species list under five genera (Family: Chalcididae)

\begin{tabular}{|c|c|}
\hline \# Genera & Species \\
\hline 1 Antrocephalus Kirby & $\begin{array}{l}\text { Antrocephalus carnifrons Cameron } \\
\text { Anthrocephalus mitys Walker } \\
\text { Antrocephalus subelongatus Kohl } \\
\text { Antrocephalus validicornis Holmgren }\end{array}$ \\
\hline 2 Brachymeria Westw & $\begin{array}{l}\text { Brachymeria euploeae Westwood } \\
\text { Brachymeria jambolana Gahan } \\
\text { Brachymeria aurea Girault } \\
\text { Brachymeria minuta Linnaeus } \\
\text { Brachymeria coxadentata Joseph et al. }\end{array}$ \\
\hline 3 Hockeria Walker & $\begin{array}{l}\text { Hockeria bengalorica Narendran } \\
\text { Hockeria bifaciata Walker }\end{array}$ \\
\hline 4 Haltichel & Unidentified sp. \\
\hline $\begin{array}{l}5 \text { Kriechbaumerella } \\
\text { Dalla Torre }\end{array}$ & $\begin{array}{l}\text { Kriechbaumerella dustructor } \\
\text { Waterston }\end{array}$ \\
\hline
\end{tabular}

Table 2: Showing the data collected from different collecting methods (YPT and SN), (Family: Chalcididae).

\begin{tabular}{llllllll}
\hline \# Genera & \multicolumn{3}{l}{ Feb '17-Jan '18 } & \multicolumn{3}{l}{ Feb '18-Jan '19 } \\
& \multicolumn{2}{c}{ YPT } & SN & Total & YPT & SN & Total \\
\hline 1 & Antrocephalus Kirby & 12 & o & 12 & 7 & o & 7 \\
2 & Brachymeria Westwood & 26 & 0 & 26 & 15 & 0 & 15 \\
3 & Hockeria Walker & 17 & 0 & 17 & 23 & 0 & 23 \\
4 & Haltichella Spinola & 7 & 0 & 7 & 14 & 0 & 14 \\
5 & Kriechbaumerella Dalla Torre & 1 & 0 & 1 & 0 & 0 & 0 \\
& 63 & 0 & 63 & 59 & 0 & 59 \\
\hline
\end{tabular}

Ambient Science (2022)

http://www.caves.res.in/

Vol.-09(1): p. 14 


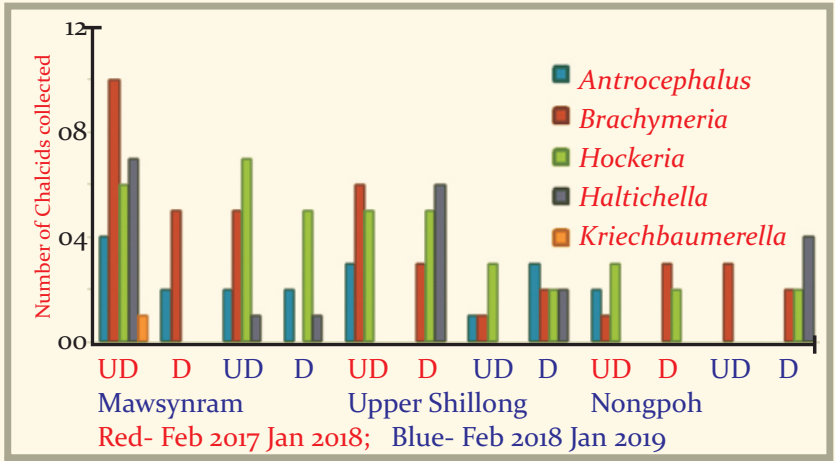

Figure-1: Bar representing the Chalcids from the disturbed and undisturbed forest of different collecting sites

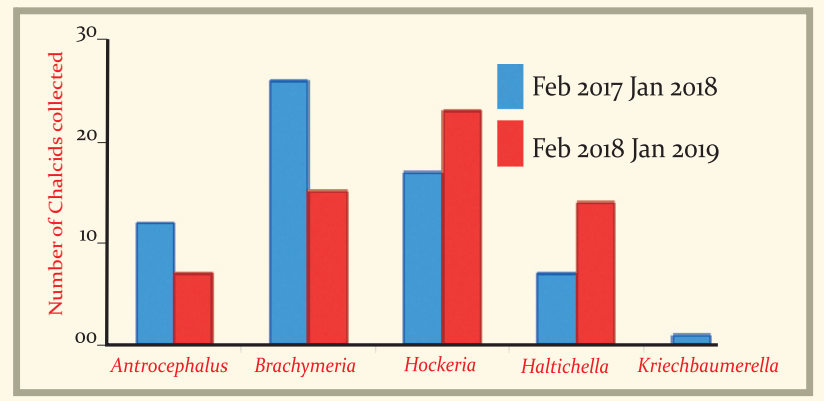

Figure-2: Bar representing the Chalcids from the period of Feb 2017-Jan 2018 and Feb 2018-Jan 2019

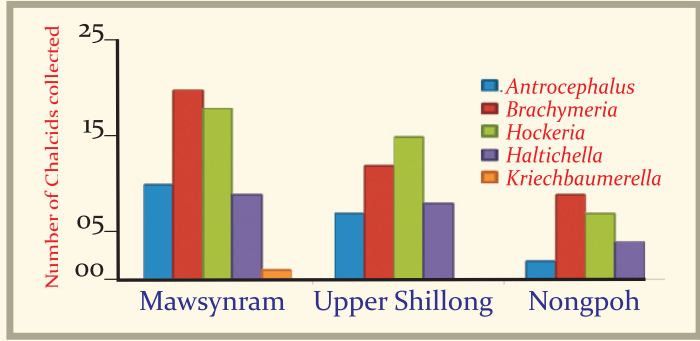

Figure-3: Bar representing the Chalcids from three different collecting sites

were used i.e. yellow pan trap and sweep net, 122 samples were only collected from yellow pan trap. In comparison to the data collected from three collecting sites, Mawsynram shows a high number of Chalcids with a total collection of 58 individuals, followed by Uppershillong with 42 chalcids and Nongpoh with a total of 22 chalcids. Brachymeria is widely distributed in all the three collecting sites, followed by Hockeria and Kriechbaumerella shows the least among the chalcids. This paper reveals that chalcids fauna is more in the undisturbed forests with plenty of vegetation unlike in disturbed forests which is the main cause for the decline of biodiversity (Brockerhoff et al., 2017) and a threat to the fauna due to habitat destruction and fragmentation. Hence further study could be conducted in the future for other Chalcidoids to be discovered and described before they becomeextinct.

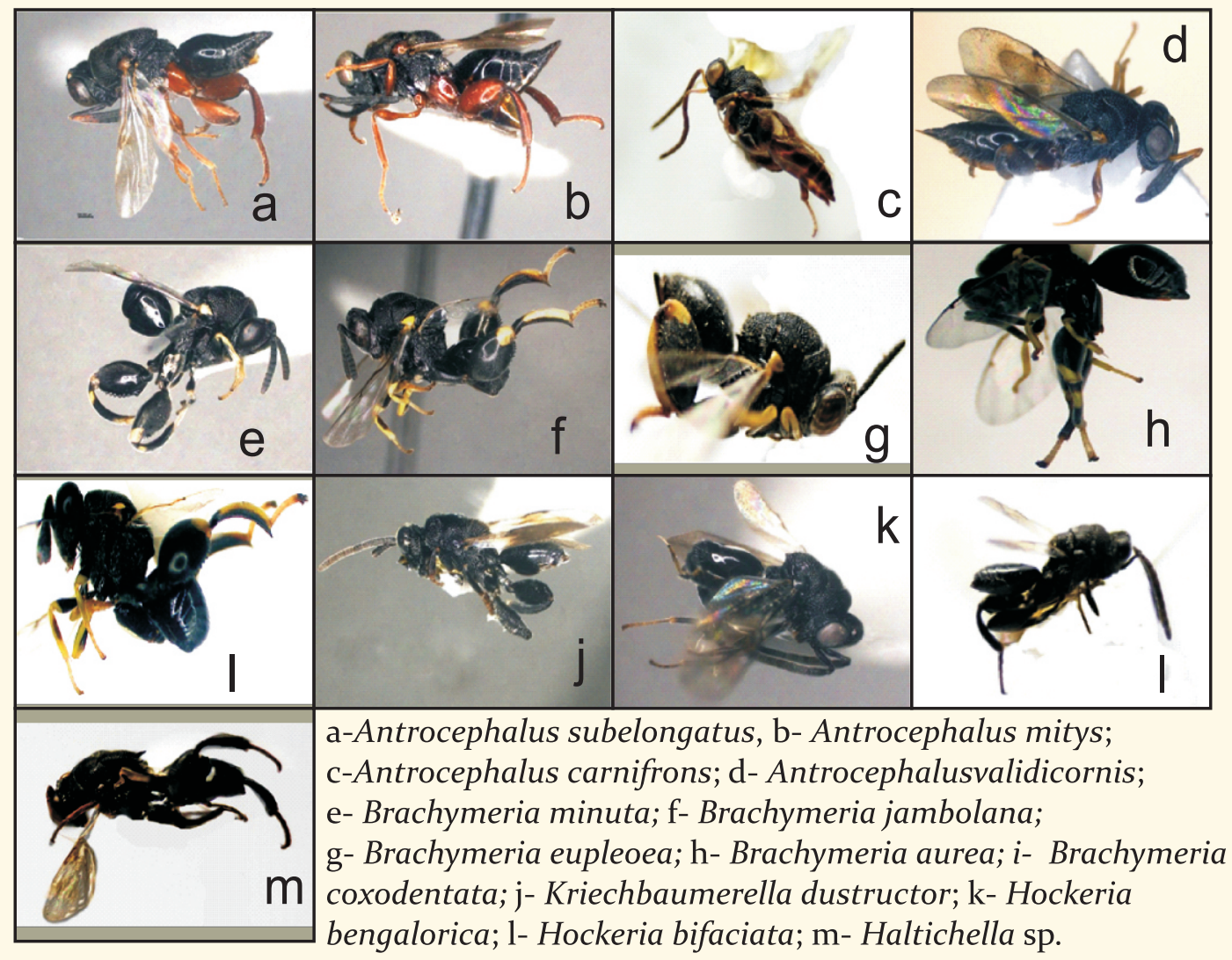

Plate-1: Images of the Chalcids identified during study from different collecting sites 


\section{References:}

Bouèek, Z. (1952): The first revision of the European species of the family Chalcididae (Hymenoptera). Acta Entomol Mus Natl Pragae., 27(1):1-108.

Boucek, Z. (1988): Australasian Chalcidoidea (Hymenoptera). A Biosystematic Revision of Genera of Fourteen Families, with a Reclassification of Species. Pub. by: $C A B$ International Wallingford, Oxon UK. 832pp.

Boucek, Z. \& Delvare, G. (1992): The new world genera of Chalcididae. Mem. Am. Entomol. Ins., 53:1-466.

Brockerhoff, E.G., Barbaro, L., Castagneyrol, B., Forrester, D.I., Gardiner, B., González-Olabarria, J. R., Lyver, P. O.B., Meurisse, N., Oxbrough, A., Taki, H., Thompson, I.D., Plas, F. \& Jactel, H. (2017): Forest biodiversity, ecosystem functioning and the provision of ecosystem services. Biodivers. Conserv., 26:3005-3035.

Delvare, G. (2017): Order Hymenoptera, family Chalcididae. $\underline{A r}$. Fau. UAE. 6:225-274.

Gowri, P.J. (2019): Morphology versus Molecular Phylogeny in Diagnosing Indian Chalcididae (Hymenoptera: Chalcidoidea). Thesis Submitted to the Annamalai University, India.

Gupta, A. (2010): First record of Brachymeria jambolana Gahan (Hymenoptera: Chalcididae) as a pupal parasitoid of Graphium doson (C. \& R. Felder) (Lepidoptera: Papilionidae).J. Biol. Count., 24(4):363-364.
Iqbal, T. \& Inayatullah, M. (2015): Two species of genus Antrocephalus Kirby (Chalcididae: Chalcidoidea: Hymenoptera): New Records for Province Khyber Pakhtunkhwa, Pakistan. J. Entomol. Zool. Stud., 3(1):295-301.

Joseph, K.J., Narendran, T.C. \& Joy, P.J. (1973): Oriental Brachymeria. A monograph on the Oriental species of Brachymeria (Hymenoptera: Chalcididae). Pub. by: University of Calicut, Zoology Monograph No 1 pp. vii+215pp.

Mani, M.S. (1989): The Fauna of India and the adjacent countries Chalcidoidea (Hymenoptera) Part 1. Pub. by: Zoological Survey of India, Govt. of India.

Narendran, T.C. (1986): Family Chalcididae. In: Subba Rao, B.R. \& Hayat, M. (Eds) - The Chalcidoidea (Insecta: Hymenoptera) of India and the adjacent countries. Orient. Insects. 20:18.

Narendran, T.C. \& Achterberg, C.V. (2016): Revision of the family Chalcididae (Hymenoptera, Chalcidoidea) from Vietnam, with the description of 13 new species. Zool. Keys, 576:1-202.

Noyes, J.S. (1982): Collecting and preserving chalcid wasps (Hymenoptera: Chalcidoidea).J. Nat. Hist., 16:315-334.

Sheela, S., Narendran, T.C. \& Tiwari, R.N. (2003): Contribution to the knowledge of Chalcididae of India. Rec. Zool. Surv. India, 101(3-4):247-266.

Thakur, N.S.A. (1990. Additional record of parasitoids (Brachymeria lasus, Ascogaster sp.) on soyabean leaf folders, Nacoleia spp. in Khasi Hills of Meghalaya (India). India. J. Hill Farm., 3(2):83-84.

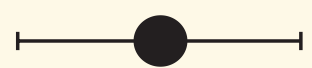

